\title{
Feeding Habit of Heterotis niloticus of Kugbo Creek in Niger Delta, Nigeria.
}

\author{
$*^{1}$ Edoghotu A. J. and ${ }^{2}$ I. A. Hart \\ ${ }^{I}$ Department of Biology, Ignatius Ajuru University of Education, Rumuolumeni, Port Harcourt. \\ ${ }^{2}$ Department of Animal and Environmental Biology, University of Port Harcourt.
}

\begin{abstract}
The feeding habit of Heterotis niloticus of Kugbo Creek in the Niger Delta region of Nigeria had been studied in 20 stomach samples. Food items were evaluated by total food weight and simple visual inspection of stomach content methods. Point were allotted relative to standard stomach weight (SW) of $0.20 \mathrm{~g}$. Values range of Frequency of Occurrence $\left(F_{i}\right)$ of the $i$ food item in the sample was $15.00 \%$ to $75.00 \%$, a Volumetric Analysis Index of the i food item in the sample $\left(V_{i}\right)$ was $1.875 \%$ to $17.50 \%$ while Importance Index $\left(A I_{i}\right)$ of the $i$ item in the sample $\left(\mathrm{AI}_{2}\right)$ was $28.125 \%-2187.5 \%$. Food items observed were the MacrophytesCeratophyllum sp.; Algae (phytoplankton)- Spirogyra crassa, S. fluviatilis, S. setiformis, Mycrosytis aeruginosa and Cymbella cistula while Zooplankton were Rotifera-Monostyla humata, M. lunaris and Polyphemis pediculus; Ostracoda was Cyclocypress sp.; Copepoda were Eucyclops sp., Thermocyclops sp and Cyclops nauplus, Cladoccra was Daphnia sp.; worms and insects larvae.
\end{abstract}

Keywords: Heterotis niloticus, Kugbo Creek, Niger Delta, Feeding Habit, Stomach Content and Omnivorous.

\section{Introduction}

Heterotis niloticus (cuvier), commonly known as African Bony Tongue or African Arowana belongs to the family Osteoglossidae. It is a primitive freshwater Teleosti (Lagler et al., 1978) that is easily identified by its long, regular shape, spineless dorsal and anal fins, small rounded tail relative to body size, wide cycloid scales except head, terminal mouth with thick lips, short head with large sensory pith and lateral line extending from operculum to the middle of caudal peduncle (Idodo-Umeh, 2003 and Reed et al., (1967). The fish is widely distributed in tropical Africa. In Nigeria for instance, some authors had reported its occurrence in some part of the country.

Nwabueze and Nwabueze (2010) reported its occurrence in Delta State, Southern Nigeria; Reed et al., (1967) in Northern Nigeria, Mustapha, M. K. (2010) in Oyun Reservoir, Offer, Nigeria, and Ekwu and Udoidiong (2011) in Cross River Basin. Heterotis niloticus feeding habit had been described to be microphagus fitter feeder, feeding on small invertebrates, small seed and mostly plankton Reed et. al., (1967) and Ekanem et al., (2010). The Kugbo Creek has been a very conducive habitat for species due to its large swamps and flood plains which serves as breeding ground. The indigenous fishers of Kugbo Creek knew little or nothing about its feeding habit and have assumed it does not eat, since unlike other fishes, they only find minute particles in the stomach while processing them for food. This speculation among the fishers had therefore prompted this study, which was aimed at establishing the true diet composition of species in the creek.

\section{Materials and Methods}

Kugbo Creek (Latitude $4^{\circ} 40^{\prime} \mathrm{N}, 4^{\circ} 49^{\prime} \mathrm{N}$ and Longitude $6^{\circ} 20^{\prime} \mathrm{E}, 6^{\circ} 35^{\prime} \mathrm{E}$ ) is linked upstream to Orashi River and Kolo Creek while it empties downstream into Santa Barbara estuary.

\section{Sampling}

Fish stomach samples collected within March, 2009 to February 2011 (24 months) in 3 zones (freshwater zone 1, fresh/brackish water zone 2 and brackish water zone 3) of the Creek were extracted by dissection. The stomach content of 20 individual fishes were analyzed to establish feeding habit of the species according to the procedures of Lima- Junior and Goitein (2001). It was based on three indices methods of Frequency of Occurrence $\left(\mathrm{F}_{\mathrm{i}}\right)$, Volumetric Index $\left(\mathrm{V}_{\mathrm{i}}\right)$ and Importance Index methods $\left(\mathrm{AI}_{\mathrm{i}}\right)$. Food items (i) were identified with either mere visual inspection or microscopy. Values of each method were presented in percentage ratio. The three methods consist of evaluation of food items from total food weight and simple visual inspection of stomach content. Lima-Junior and Goitein (2001) observed that the methods of counting, weighing or volumetrically quantifying in an individualized way was often impossible. An alternative method based on attribution of points was then suggested by Hoynes, (1950) and later adopted by Lima-Junior et al., (2000).

The methods was by inferring relative abundance of food items from simple visual inspection of each stomach contents and attribution of points to food categories based on their volumes in relation to stomach volume. The mathematical evaluations of the three methods here adopted in this work were as follows: 
1. Frequency of occurrence $\left(\mathrm{F}_{\mathrm{i}}\right)$

$$
\mathrm{F}_{\mathrm{i}} \quad=\quad 100 \mathrm{ni} / \mathrm{n}
$$

Where;

$\mathrm{F}_{\mathrm{i}} \quad=\quad$ frequency of occurrence of the $\mathrm{i}$ food item in sample.

$\mathrm{N}_{\mathrm{i}} \quad=\quad$ number of stomach in which the $\mathrm{i}$ item is found

$\mathrm{n} \quad=\quad$ total number of stomach with food in it

2. Volumetric Analysis Index $\left(\mathrm{V}_{\mathrm{i}}\right)$ was used to deduce the relative abundance of the $\mathrm{i}$ food item found in stomach samples. Its calculation was based on ascribed points to distinct i food items after a simple visual inspection on the stomach's food contents. The procedure was executed by a constant reference weight called standard weight (SW or WS). SW is defined as the arithmetic mean of weight of stomach content of specimen obtained in previous collections. The calculated SW of the first sample representing $100 \%$ was used as a constant reference value for analysis of the subsequent samples with which comparisons were made.

Points were ascribed using integers $(1-8)$ to each stomach analyzed, according to its proportional weight in relation to the SW. For the purpose of this work, four points were adopted. An empty stomach with its total content representing a weight of approximately $25 \%$ of the SW was ascribed 1 point. Also, stomachs with total content double the SW received 8 points.

Points were distributed to the stomach items in proportion to the volume each item occupied. Fractional points or values, where necessary, were assigned 0.5 since inspections were subjective. Stomach contents composed of many items that the whole received only 1 point, the point was divided between the two most abundance items in the stomach.

Consequently, the less abundant items failed to receive any punctuation (or assigned 0 ). The points ascribed to each food item in a sample of stomachs were transformed into an arithmetic mean, or rather, the value that represent the mean abundance of the determined food item in the sample as follows:

$$
\begin{aligned}
\mathrm{M}_{\mathrm{i}} & =\quad \sum_{i} / n \\
\text { Where; } & =\quad \text { mean of the ascribed points for the } \mathrm{i} \text { food item; } \\
\sum_{i} & =\quad \text { sum of the ascribed points for the } \mathrm{i} \text { food item; } \\
\mathrm{n} & =\quad \text { total number of stomach with food in the sample }
\end{aligned}
$$

The values of $\mathrm{M}_{\mathrm{i}}$ calculated for each food item, was within value range of 0 to 4 . These values were transformed into percentage ratio or the food volumetric for easy analysis into interpretation of results by the formula;

Where;

$$
\mathrm{V}_{\mathrm{i}}=25 \mathrm{M}_{\mathrm{i}}
$$

$\mathrm{V}_{\mathrm{i}}=\quad$ Volumetric analysis index of the $\mathrm{i}$ food item in the sample;

$25=$ the multiplication constant to obtain a percentage;

$\mathrm{M}_{\mathrm{i}}=$ mean for the $\mathrm{i}$ food item

3. Importance index. $\left(\mathrm{A} 1_{\mathrm{i}}\right)$ : was used to determine relative importance of a determined food category (item) plays in the fish's diet. It is obtained separately for each food item by the following formula;

$\begin{array}{lll} & \mathrm{A} 1_{\mathrm{i}}=\quad \mathrm{F}_{\mathrm{i}} \times \mathrm{V}_{\mathrm{i}} \\ \text { Where; } & & \text { Importance index of the } \mathrm{i} \text { food item in the sample; } \\ \mathrm{A} 1_{\mathrm{i}}= & \text { Occurrence frequency of the items; } \\ \mathrm{F}_{\mathrm{i}}= & \text { Volumetric analysis index of the item. } \\ \mathrm{V}_{\mathrm{i}}= & \end{array}$

\section{Results and Discussion}

Results of the study are presented in Tables 1 and 2. Stomach content of the 20 species of Heterotis nitoticus reveled that the fish is omnivorous in habit. The food items found in stomachs consist of macrophytes, plankton, insects and worms. Macrophytes were Ceratophyllum ceravisia with Frequency of Occurrence index $\left(\mathrm{F}_{\mathrm{i}}\right)$ range of $15.00 \%-75.00 \%$, Volumetric Analysis Index $\left(\mathrm{V}_{\mathrm{i}}\right)$ 1.875\% - 17.50\%, Importance Index $\left(\mathrm{AI}_{\mathrm{i}}\right)$ 28.125\%-1312.50\%. Algae were the most preferred food items. Five algae species in three families. Chlorophycea were Spirogyra crassa, S. fluviatilis, S. setiformis; Bacillariophyceae - Cymbella cistula and 
Feeding Habit of Heterotis niloticus of Kugbo Creek in Niger Delta, Nigeria.

Cyanobacteria - Mycrocystis aeruginosa were identified among the food items with high percentage indices except Cymbella and Mycrocystis. Highest consumed among the Chlorophyceae was S. setiformis. Its Occurrence Frequency $\left(\mathrm{F}_{\mathrm{i}}\right)$ was $75.00 \%$, Volumetric Analysis $\left(\mathrm{V}_{\mathrm{i}}\right) \mathbf{1 7 . 5 \%}$ while Importance Index $\left(\mathrm{AI}_{\mathrm{i}}\right)$ was 1312.50\%. S. fluviatilis with $\mathrm{F}_{\mathrm{i}} 65.00 \%, \mathrm{~V}_{\mathrm{i}} 14.375 \%, \mathrm{~A} 1_{\mathrm{i}} 1312.50 \%$ and $\mathrm{S}$. crassa had $\mathrm{F}_{\mathrm{i}} 65.00 \%, \mathrm{~V}_{\mathrm{i}} 11.25 \%$, and $F_{i}$ 1565.50. This suggest that, aside filter feeding, the fish grazed on aufwuch community represented by the three Chlorophyceae species by scraping, nimble or nipping the plants off their substrate. Hence, the presence of a small quality of muddy substance (detritus) in the food composition is evidence to the fact. This selective feeding process also enhance their ability of the fish to avoid or resist baited hooks, of fishers but are easily trapped with ordinary plant leaves used as bait and left floating over their breading nest during the breading season, in early rainy season (May to July).

The Zooplankton community was the least preferred as evidence in their indices Rotifera consist of Monostyla hamata, M. lunaris and Polyphemus pediculus. Monostyla hamata had highest Occurrence Frequency $\left(\mathrm{F}_{\mathrm{i}}\right)$ of $55.00 \%$, Volumetric Analysis $\left(\mathrm{V}_{\mathrm{i}}\right)$ and Importance Index $\left(\mathrm{AI}_{\mathrm{i}}\right)$ was $481 \%$. Other groups of Zooplankton found in the stomach samples were Ostracoda represented by Cyclocypress sp, Copepoda represented by Eucyclops sps, Thermocyclops sps, and Cyclops nauplus and Cladocera by Daphnia sps. Occurrence Frequencies $\left(\mathrm{F}_{\mathrm{i}}\right)$ ranged from $15.00 \%$ to $55.00 \%$ while $\mathrm{V}_{\mathrm{i}} 1.875 \%$ and $\mathrm{A} 1_{\mathrm{i}}$ Was $28.125 \%-481.25 \%$ of all. This observation also further showed how less the fish dependences on Zooplankton organisms.

However, the indices values for insects' larvae were relatively high. They also suggest that, while the other Zooplankter is not their favorites, the insect larvae were taken in preference.

Table 1: Ascribed points to each food item of the twenty stomach contents and mean ascribed points $\left(\mathrm{M}_{\mathrm{i}}\right)$ to each i food item

\begin{tabular}{|c|c|c|c|c|c|c|c|c|c|c|c|c|c|c|c|c|c|c|c|c|c|c|}
\hline \multirow{2}{*}{$\begin{array}{l}\text { Food } \\
\text { item (i) }\end{array}$} & \multicolumn{22}{|c|}{ Stomachs } \\
\hline & 1 & 2 & 3 & 4 & 5 & 6 & 7 & 8 & 9 & 10 & 11 & 12 & 13 & 14 & 15 & 16 & 17 & 18 & 19 & 20 & $\begin{array}{l}\text { Point } \\
\text { total }\end{array}$ & $\mathrm{Mi}$ \\
\hline $\begin{array}{l}\text { Assigned total } \\
\text { points }\end{array}$ & 4 & 2 & 4 & 4 & 8 & 4 & 6 & 4 & 8 & 8 & 4 & 2 & 2 & 2 & 6 & 6 & 2 & 4 & 4 & 2 & & \\
\hline \multicolumn{23}{|l|}{ Macrophytes } \\
\hline $\begin{array}{l}\text { Ceratophyllum } \\
\text { ceravicia }\end{array}$ & 0.5 & & 0.5 & 1 & 1 & & & & 0.5 & 1 & 0.5 & & & & 1 & & 0.5 & & & & 5.5 & 0.275 \\
\hline \multicolumn{23}{|l|}{ Algae } \\
\hline Spirogyra crassa & 1 & 0.5 & & 1 & 1 & 0.5 & & 0.5 & 0.5 & 0.5 & & & & 1.5 & 0.5 & & 0.5 & & 0.5 & 0.5 & 9.0 & 0.45 \\
\hline S. fluviatilis & & 0.5 & 0.5 & 0.5 & & 1 & 0.5 & 1 & 1 & 1 & 0.5 & 0.5 & & & 1.5 & 2.5 & & 0.5 & 1 & & 11.5 & 0.575 \\
\hline S. setiformis & 1 & 0.5 & & 0.5 & 0.5 & & 1 & & 1 & 0.5 & & 0.5 & & 0.5 & 1.5 & $0.5^{-}$ & 1 & 0.5 & 2.5 & & 14.0 & $0.7^{-}$ \\
\hline \multicolumn{23}{|l|}{ Rotifera } \\
\hline Monostylla hamata & & 0.5 & & 0.5 & 1 & 0.5 & 0.5 & & 1 & 1 & 0.5 & & & & 0.5 & 0.5 & & & & 0.5 & 7.0 & 0.35 \\
\hline M. lunaris & & & 0.5 & 0.5 & 0.5 & 0.5 & 1 & 0.5 & & & 0.5 & & & & & & & & & & 4.0 & 0.2 \\
\hline $\begin{array}{l}\text { Polyphemis } \\
\text { pedicullus }\end{array}$ & & & & & 0.5 & 0.5 & 0.5 & & 0.5 & & 0.5 & & 1 & & & 1 & & & & 0.5 & 5.0 & 0.25 \\
\hline \multicolumn{23}{|l|}{ Ostacoda } \\
\hline Cyclocypress sp. & & & 0.5 & & 0.5 & & 0.5 & & 1 & & & & & & & & & 0.5 & & & 3.5 & 0.175 \\
\hline \multicolumn{23}{|l|}{ Copepoda } \\
\hline Eucyclops sp. & & & 0.5 & & & 0.5 & 0.5 & & 0.5 & 1 & & & & & & 0.5 & & & & & 3.5 & 0.175 \\
\hline Thermocyclops sp. & 0.5 & & 0.5 & & 0.5 & & 0.5 & & 1 & & & & & & & & & & & & 3.0 & 0.15 \\
\hline Cyclops nauplus & & & & & 0.5 & & 0.5 & & & 1 & 0.5 & & 0.5 & & & & & & & & 3.0 & 0.15 \\
\hline \multicolumn{23}{|l|}{ Cladocera } \\
\hline Daphnia sp. & & & 0.5 & & 0.5 & & & 0.5 & & 0.5 & & & & & & 0.5 & & & & & 1.5 & 0.075 \\
\hline Worms & & & & & & & 0.5 & 0.5 & & & & & & & & & & 0.5 & & & 1.5 & 0.075 \\
\hline \multicolumn{23}{|l|}{ Insecta } \\
\hline Insects larvae & & & & & 0.5 & & & 0.5 & 0.5 & 1.5 & 0.5 & 1 & & & & 0.5 & & 1 & & & 3.0 & 0.15 \\
\hline Detritus & 0.5 & & 0.5 & & 1 & & & 0.5 & 0.5 & 1 & 0.5 & & 0.5 & & & & & 1 & & 0.5 & 6.5 & 0.325 \\
\hline Assign total points & & & & & & & & & & & & & & & & & & & & & & \\
\hline
\end{tabular}

Table 2: Occurrence Frequency $\left(\mathrm{F}_{\mathrm{i}} \%\right)$, Volumetric Index $\left(\mathrm{V}_{\mathrm{i}} \%\right)$ and Importance Index $\left(\mathrm{A} 1_{\mathrm{i}} \%\right)$ for each $\mathrm{i}$ food items in Heterotis niloticus stomach sample of Kugbo Creek within March 2009 - February 2011.

\begin{tabular}{llll}
\hline Food item (i) & $\mathbf{f i}(\boldsymbol{\%})$ & $\mathbf{V i}(\boldsymbol{\%})$ & $\mathbf{A 1 i}(\boldsymbol{\%})$ \\
\hline $\begin{array}{l}\text { Macrophytes } \\
\text { Ceratophyllum ceravicia }\end{array}$ & 40.00 & 6.875 & 275 \\
Algae & & & \\
Spirogyra crassa & 65.00 & 11.25 & 731.25 \\
S. fluviatilis & 65.00 & 14.375 & 934.375 \\
S. setiformis & 75 & 17.5 & 1312.5 \\
Rotifera & & & \\
Monostylla hamata & 55.00 & 8.75 & 481.25 \\
M. lunaris & 35.00 & 5.00 & 175 \\
$\begin{array}{l}\text { Polyphemis pedicullus } \\
\text { Ostracoda }\end{array}$ & 40.00 & 6.25 & 250 \\
Cyclocypress sp. & & & \\
Copepoda & 25.00 & 4.375 & 109.375 \\
$\begin{array}{l}\text { Eucyclops sp. } \\
\text { Thermocyclops sp. }\end{array}$ & & & \\
Cyclops nauplus & 30.00 & 4.373 & 131.19 \\
\end{tabular}


Feeding Habit of Heterotis niloticus of Kugbo Creek in Niger Delta, Nigeria.

\begin{tabular}{llll} 
Cladocera & & & \\
Daphnia sp. & 25.00 & 1.875 & 46.875 \\
Worms & 15.00 & 1.875 & 28.125 \\
Insecta & & & \\
Insects larvae & 20.00 & 3.75 & 150 \\
Detritus & 50.00 & 8.125 & 406.25 \\
\hline
\end{tabular}

\section{References}

[1]. Ekanem A.P., C.B.Ndome, and M.N. Osuagwu (2010). Techniques in the improvement of consumers taste of Heterotis niloticus. African Journal of Food science 4(10): 676-678.

[2]. Ekwu and Udoidiong (2011). Observations of Heterotis niloticus. (Cuvier) in the Cross River Basin: an introduced species. Nigerian Journal of Fisheries 8(2): 365-370

[3]. Hynes, H.B.N. (1950). The food of freshwater stickle backs (Gasteros teus aculeatus and Pygosteous Pungitius) with a review of methods used in studies of the food of fishes. J. Anin. Ecol. Oxford, V. 19P - 36-38.

[4]. Idodo-Umeh G. (2003). Freshwater fishes of Nigeria (Taxonomy, ecological notes, diet)

[5]. Larger, K.F. (1978). Freshwater Fisheries Biology C. Brown Company Ltd. 41P.

[6]. Largler K. F., J.E. Bardach, R.R. Miller and D.R.M. Passino (1977). Ichthiology, $2^{\text {nd }}$ edition. John Wilyey and Sons, New York, USA.

[7]. Lima-Junior S.E. (2000). Diete e condicdo de Pimelodus maculates (Osteichthyes, Instituto de Biociencias, Universidide Estadual Paulista. Rio Clara.

[8]. Lima-Junior S.E. and R. Giotein (2001) A new method for the analysis of fish stomach contents 4cta Scientiarum, Maringa 23(2) P. 421-424.

[9]. Mustapha, M.K. (2010). Heterotis niloticus (Cuvier 1929). A threatened fish in Oyun Reservior, Offa, Nigeria: the need for its conservation. Asian Journal of Experimental Biological Scien, 1(1): 1-7

[10]. Nwabueze A. A. and E.O. Nwabueze (2010)

[11]. Reed, W., J. Burchard, J. Jennes and I. Yaro (1967). Fish and Fisheries of Northern Nlgeria. MAO. 226pp. 